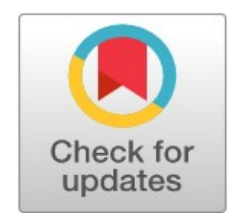

PRIMARY RESEARCH

\title{
The use of stories in promoting morality among junior high school students
}

\author{
Danesh Shams ${ }^{1, *}$ \\ ${ }^{1}$ Department of Curriculum Design, National Dong Hwa University, Taiwan
}

\author{
Keywords: \\ Morality \\ Degeneration \\ Virtue \\ Story
}

Received: 9 April 2016

Accepted: 21 April 2016

Published: 21 June 2016

\begin{abstract}
The main objective of this study was to show that storytelling can be a very effective tool for teaching and promoting morality. The author used action research design to explore and understand morality among junior high school students and the use of stories as a form of interventionary strategy. This is a research design that lends itself to use in school and community situations. It is solution-driven and has the potential to increase the amount researchers learn from their experience. This study shows that storytelling can be a very effective tool for teaching and promoting morality. This study is designed to improve practice and advocate for change. This research shows a clear influence of storytelling on the awareness of moral issues among junior high school students.
\end{abstract}

(C) 2016 The Author(s). Published by TAF Publishing.

\section{INTRODUCTION}

We live in a very special age. Humanity as a whole has been going through tremendous changes. These changes have brought about many challenges and promises. The world we live in is becoming smaller as the days go by. Because of tremendous progress in the fields of communication and transportation, countries are no longer able to claim that what they do in their own backyards are internal affairs that should not concern other countries. A global society is being born. Internationalization is the name of the game in many areas of endeavor such as science, education, and business. Information technology and biotechnology have revolutionized, and will continue to revolutionize the fortunes of humanity. All of this progress and improvement has brought many challenges. There is a question of ethics in every discovery that is being made and in every bit of progress that is being achieved. Humanity, mindful of the abuses inflicted upon it by religions and religious leaders in the past and present, is hesitant to apply the laws of religion to meet the challenges created by ethical questions in science and the humanities. Even if the world were prepared to accept religious teachings for the purpose of solving ethical

\footnotetext{
*Corresponding author: Danesh Shams

E-mail: daneshshams99@gmail.com
}

The Author(s). Published by TAF Publishing. This is an Open Access article distributed under a Creative Commons AttributionNonCommercialNoDerivatives 4.0 International License 
challenges, we would have tremendous difficulty choosing a single religion acceptable to all.

None of the above difficulties can extinguish the need for a moral code of conduct. We, as human beings, have no choice but to find a way to rescue ourselves from the mess we are in. A single glance at current statistics clearly indicates the state of society: increases in violence, drug abuse, child abuse and divorce on one hand, and the proliferation of indecent materials on the other; corruption of politicians and political systems on one hand, and prostitution of the press on the other. These are signs and portents that the foundation of society is crumbling, and no light is discernible at the end of the tunnel.

With the above in mind, the need for moral education seems abundantly clear. In the words of Judge (2015), "an established morality is as necessary as good government to the welfare of society. Societies disintegrate from within more frequently than they are broken up by external pressures."

The moral education being promulgated in this study dedicates itself to creating an environment in which human virtues can be planted, nurtured, loved and cared for, at the earliest age, so that the future society will be a safer and gentler one.

I am a teacher and have been a teacher for the last twenty-seven years. I am concerned about the decline in the morality of students and changes in their attitudes towards learning. I believe there is a direct link between the promotion of morality and development of proper attitudes among students. In conducting this research, I am motivated by the specific fact that it brings me joy and satisfaction to see my students grow with proper attitude towards life and its purpose. It is my hope and expectation to find a workable solution to offer teachers to use in dealing with moral aspects of their students.

\section{Definition of the Terms}

Morality: principles concerning the distinction between right and wrong or good and bad behavior.

Degeneration: a lowering of effective power, vitality, or essential quality to an enfeebled and worsened kind or state.

Virtue: virtue is a positive trait or quality deemed to be morally good and thus is valued as a foundation of principle and good moral being.

Story: "Story" comes from the Latin historia, meaning a relation of events through oral or written means. The word "narrative" comes from the Latin narrātivvus which means to relate or to "make known," so it is a very close cousin of story. Indeed, according to the Oxford English Dictionary story is defined as "a narrative," and narrative is defined as a "tale, story, recital (of facts, etc.)."

\section{LITERATURE REVIEW}

The use of stories in teaching morality is not a new idea. It has existed in both the Chinese and Western cultures. The Bible, the most influential book of Western civilization, is filled with stories, particularly parables in the New Testament. On the Chinese side, we see the use of stories in Confucian ethics portraying good judgments by good individuals. It is generally recognized that there is a contemporary revival of virtue ethics, but reasons for this are varied. One is the degrading condition of morality in presentday society; the other is an 
attempt on the part of some thinkers to guide the process by emphasizing general principles of action rather than emphasis on ideal character traits (Stanford Encyclopedia, 2014). I think a very brief review of Western and Chinese virtue ethics is helpful at this juncture.

A close study of Confucius' thoughts on virtue ethics reveals his emphasis on three main subjects: identification of individual character as virtue, the meaning of a good life and what philosophers refer to as "particularistic modes of ethical reasoning," meaning that the individual acts virtuously, not based on some guiding principles, but rather on judgment of the given context and situation (Van Norden, 2004; 2007). Confucius mentions some of the virtues that "the noble person" (jun君 zi 子) possesses: humaneness (ren人wen文), benevolence (ren人 xin心), filial piety (xiao孝 shun順), righteousness (yi義), and acting according to ceremonial ritual or more generally propriety (li禮), (Stanford Encyclopedia 2014).

The concept of righteousness (yi 義) makes the case for acting in a way that is proper in a given situation. For example, the Analects 4:10 states that the jun zi is not predisposed to be for or against anything, but rather goes with what is yi. In other words, one can act respectfully or politely in dealing with others based on traditional values, but it is yi that dictates under what circumstances those actions should be set aside (Cua, 1997). A very good example of this is of Shun and his father, where the duties of a ruler might intersect with his filial duties, and he must learn how to act, based on reflection on the situation. At the same time, one important point is the Confucian idea one has to serve one's parents in a manner such that it becomes an internal quality or second nature to the individual (Cuo, 1997; Kupperman, 1999). The internalization of a virtue should be, in my opinion, the ultimate purpose of any moral education.

When we look at the Western concept of virtue ethics in ancient Greek, medieval period and cotemporary sources, we see similarities between Western and Chinese thought on the subject of virtue ethics. This might explain the rise of interest in Confucius among Western thinkers. According to Yu (2007) the concept of eudaimonia (happiness, living well, flourishing) according to Aristotle, and the concept of dao (the way for human beings to live), according to Confucius, share parallel starting points in their ethics, and the next step in both their ethics is to discuss virtue. One of the points that merits attention is the indispensable role of a caring attitude towards others as a necessary quality and a source of flourishing life for an ethical individual, (Mencius, 2A6, 6A1, 6A3, and 6A7). We see a similar concept in the views of Aristotle, who was very clear to indicate it is "reason" that makes us human, and through use of our "reason" we should choose an ethical life (Nivison, 1996).

It is important to point out that there exists a debate on whether a Western notion of morality or anything similar to that exists in Confucian thinking. The answer to this debate would depend on how we define "moral" and "morality." Williams (1985) mentions if we define "moral" based on Kant's moral philosophy, we do not have an equivalent in Chinese philosophy. It has also been quite correctly pointed out that there are other significant differences between Chinese and Western virtue ethics, such as the centrality of family life in the Confucian conception of the good life, which is absent in Western thought (Cline, 2007; 2013). Another example is mentioned by Van Norden (2004; 
2007) about the moral emotion of shame which plays a crucial role in Mencius' conception of moral development, although there is no comparable role played by emotion according to Aristotle. One important aspect of any virtue ethics discussion has to do with human nature. This subject has produced intense debate among both Western and Chinese thinkers, including Mencius and Xunzi. According to Nivision (1996), it is fair to say that Confucianism offers an especially rich moral psychology.

Despite all their differences, it is noteworthy to point out that Chinese and Western virtue ethics have traditionally agreed on several virtues, such as courage, as being fundamental for the moral or ethical growth of an individual (Van Norden, 1997; 2007). It is, therefore, acceptable to conduct this study on a special virtue universal to both cultures, namely "truthfulness."

The next step is to find out if some mechanisms exist in using stories or narratives to teach morality, ethics or human virtues. I have used some in order to formulate a theory of moral education and narrative. The work of Hare $(1981 ; 1982 ; 1989)$ is a very good source for understanding the theory and how it works. According to Hare (1981), there are three levels in the use of narrative in moral education. These three levels are the content of the story, a process of story analysis, and a reflection upon the stories of oneself and society. The first level is referred to by Hare as the "intuitive level." At this level, the behavior of learners in everyday life is affected without reflection. We find learners internalizing contents of the story and acting based on what they have learned. The second level is referred to by Hare as the "critical level." Here is where reflection takes place, for it is at this level where subjects think very deeply about their actions, especially when faced with not so clear-cut cases of making moral choices. This level also provides opportunities for learners to exercise various resolutions that present themselves in stories. The third level is Hare's "meta-ethical" level, a very important level because it addresses the question of motivation and reasoning. It seems to me when it comes to some clear-cut choices on moral issues, subjects would feel little pressure or difficulty to make the right ones. However, when it comes to some choices under difficult circumstances, individuals need clear reasons for conviction to make the right choices.

I should point out that according to Hare, these levels are not necessarily hierarchical, and they are descriptive of different ways learners' moral actions can be influenced by stories. Literature concerning all three levels is rich indeed. Bennett (1988) is very helpful when it comes to the first level, namely how stories can form the content of moral action. There are many more materials available in literature concerning the second level. The works of Power et al. (1989) and Noddings (1992) are of great help for understanding the importance of a "process approach" as part of the storytelling moral education program.

The work of Kohl (1995) illustrates the importance of including stories in classroom studies to provide opportunities for students to reflect on the stories. These opportunities include reflection on stories about society and learners' own experiences for the purpose of stimulating imagination and critical thinking.

\section{DISCUSSION}

The author in this research embarks upon a solution to challenges facing educators in dealing with matters of morality and ethics, specifically in the 
context of junior high school.This study has its limitation to generalization, since it was performed using junior high school students and cannot be applied to the body of students at every level. The study is also limited, since it was conducted during one session lasting for forty minutes. Another limitation concerns the number of research subjects which was confined to about twenty students.

\section{Objectives of the Study}

The main objective of this study was to show that story telling can be a very effective tool for teaching and promoting morality. In compliance with instructional objectives as outlined by Dick and Lou (2001), I am articulating a detailed description of what students will be able to do when they complete a unit of instruction. But of this particular case, I find Mager's (1975) description more relevant because it deals with attitudes that are produced in learners, since these attitudes need to be translated into behaviors so they can be observed and measured. As for what was made available to the participants after they completed the lesson, three main areas were targeted: clarification of the issue; raising awareness of the issue; and application of the issue. The issue in this particular study is truthfulness - its concept, its comprehension and its implementation. Clarification of truthfulness deals with clarifying for students what it means to be truthful and what truthfulness actually means. Raising awareness of the issue deals with helping students comprehend the importance of truthfulness, and the consequences of both individuals and societies that are bereft of this virtue. Application of truthfulness deals with helping students to implement truthfulness in their daily lives. The pretest-posttest and content of the lesson were designed specifically to fulfill the three abovementioned objectives. Because of the limitations of this study, a clear criterion was not adopted. Nevertheless, the nature of this study promises enough to adopt a clear criterion for future studies.

\section{METHODOLOGY}

This research was conducted by adopting the systematic approach of Dick and Lou (1985), which takes into consideration a well-known model to analyze, design, develop, implement, and evaluate the intended study of curriculum construction and innovative method of instruction. My research subjects are grade seven students in a public junior high school in Taiwan. I gained access to the research subjects through a friend of mine who teaches there. My research subjects are teenagers who, by virtue of their age, respond better to lessons taught in story format. According to Naes and Hanay (1972) Chinese philosophy is "wisdom" literature, composed primarily of stories and sayings designed to move the audience to adopt a way of life or to confirm the adoption of that way of life. It is, therefore, very natural to conduct this study in a Chinese classroom.

\section{Research Instruments}

Academic achievement test. The instrument used in this study is based on the Academic Achievement Test. The author, in order to examine the effectiveness of students' learning, conducted a pretest-posttest evaluation. The author evaluated the results in drawing upon the posttest. The test's structure was designed according to contents of the lesson plan and literature review. 
TABLE 1. Students' performance on the pretest

Item

$$
\begin{array}{llllllll}
1 & 2 & 3 & 4 & 5 & 6 & 7 & 8
\end{array}
$$

Students

1011

$\begin{array}{lllll}12 & 13 & 14 & 15 & \text { Right Answer }\end{array}$

(\%) of

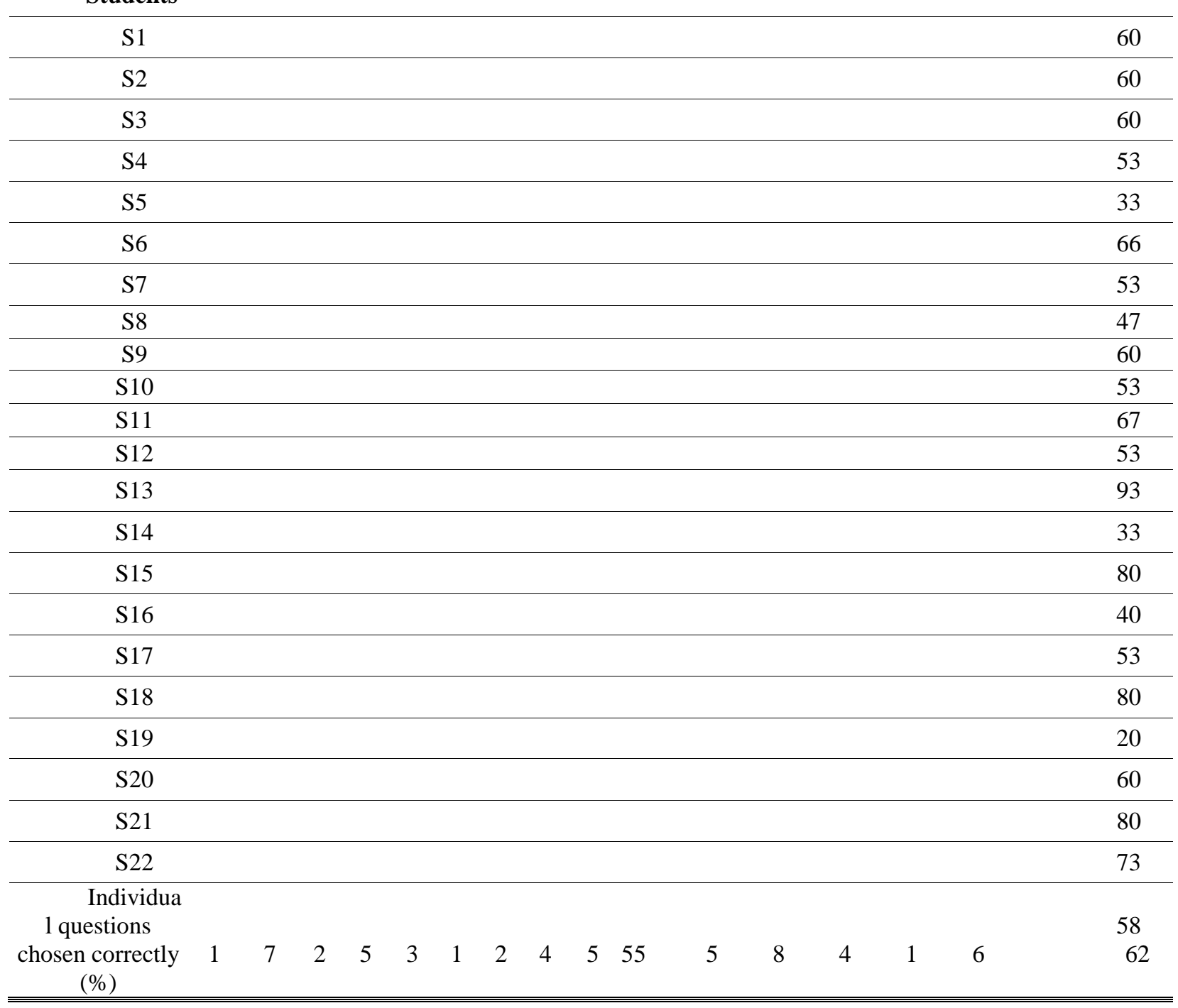

\section{Analysis of Pretest}

Overall results indicate that the majority of students had correctly answered questions put to them. The percentage of correct respondents was 58\%; this indicates a slight majority. The overall results for questions correctly chosen were also in the majority. The percentage of all questions correctly chosen was $62 \%$. Questions 7, 11 and 14 received the lowest mark, while question 1 achieved the highest mark. It is noteworthy that question 1 , which received the highest mark, is a conceptual question dealing with the first and second objectives of the study, while question 6 receiving the lowest mark deals with the third objective. This suggests that learners may have difficulties as to how 
the concept applies to different conditions. In other words, is there a clear and direct relationship between the concept, in this case truthfulness, and application of this principle? The results may be in the negative, meaning under different conditions, a different application of the principle may occur. In terms of student performance S5, S14 and S19 received the lowest mark, below passing, while S13, S16, S18 and S21 received the highest.

TABLE 2. Students' performance on the posttest

\begin{tabular}{|c|c|c|c|c|c|c|c|c|c|c|c|c|c|c|c|c|}
\hline $\begin{array}{l}\text { Item } \\
\text { Students }\end{array}$ & 1 & 2 & 3 & 4 & 5 & 6 & 7 & 8 & 9 & 10 & 11 & 12 & 13 & 14 & 15 & $\begin{array}{c}(\%) \text { of } \\
\text { Right Answers }\end{array}$ \\
\hline S1 & & & & & & & & & & & & & & & & 73 \\
\hline S2 & & & & & & & & & & & & & & & & 80 \\
\hline S3 & & & & & & & & & & & & & & & & 80 \\
\hline S4 & & & & & & & & & & & & & & & & 73 \\
\hline S5 & & & & & & & & & & & & & & & & 67 \\
\hline S6 & & & & & & & & & & & & & & & & 53 \\
\hline S7 & & & & & & & & & & & & & & & & 60 \\
\hline S8 & & & & & & & & & & & & & & & & 53 \\
\hline S9 & & & & & & & & & & & & & & & & 60 \\
\hline S10 & & & & & & & & & & & & & & & & 60 \\
\hline S11 & & & & & & & & & & & & & & & & 53 \\
\hline S12 & & & & & & & & & & & & & & & & 53 \\
\hline S13 & & & & & & & & & & & & & & & & 53 \\
\hline S14 & & & & & & & & & & & & & & & & 87 \\
\hline S15 & & & & & & & & & & & & & & & & 80 \\
\hline S16 & & & & & & & & & & & & & & & & 80 \\
\hline S17 & & & & & & & & & & & & & & & & 87 \\
\hline S18 & & & & & & & & & & & & & & & & 73 \\
\hline S19 & & & & & & & & & & & & & & & & 73 \\
\hline S20 & & & & & & & & & & & & & & & & 87 \\
\hline S21 & & & & & & & & & & & & & & & & 67 \\
\hline $\mathrm{S} 22$ & & & & & & & & & & & & & & & & 60 \\
\hline \multirow{3}{*}{$\begin{array}{l}\text { Individual } \\
\text { questions chosen } \\
\text { correctly }(\%)\end{array}$} & & & & & & & & & & & & & & & & 75 \\
\hline & & & & & & & & & & & & & & & & \\
\hline & 00 & 7 & 2 & 7 & 6 & 4 & 5 & 7 & 5 & 4 & 0 & 7 & 7 & 5 & 1 & 64 \\
\hline
\end{tabular}

\section{Analysis of Posttest}

Overall results indicate that the majority of students had the correct answers to questions put to them. The percentage of correct respondents was 64\%; this indicates a clear majority. The results for questions correctly chosen are also in a majority. The percentage of all questions correctly chosen was $75 \%$. Questions 7, 11 and 14 persisted in receiving the lowest mark, while question 1 repeated its highest mark position. It is noteworthy that question 1, which received the highest mark, is a conceptual question dealing with first and second objectives of the study, and question 6, which received the lowest mark deals with the third objective of study. In terms of student performance S17 and 
S20 achieved the highest mark, while none of the students performed below the passing mark.

TABLE 3. Comparisons of pretest and posttest scores-individual students choosing the correct answers

\begin{tabular}{lrrrllllllllllllr}
\hline \multicolumn{1}{c}{ Test Item } & $\mathbf{1}$ & $\mathbf{2}$ & $\mathbf{3}$ & $\mathbf{4}$ & $\mathbf{5}$ & $\mathbf{6}$ & $\mathbf{7}$ & $\mathbf{8}$ & $\mathbf{9}$ & $\mathbf{1 0}$ & $\mathbf{1 1}$ & $\mathbf{1 2}$ & $\mathbf{1 3}$ & $\mathbf{1 4}$ & $\mathbf{1 5}$ & 0verall 1\% \\
\hline Pretest & 91 & 77 & 82 & 55 & 73 & 41 & 32 & 64 & 50 & 55 & 45 & 68 & 64 & 41 & 86 & 62 \\
\hline Posttest & 100 & 77 & 82 & 77 & 86 & 64 & 45 & 77 & 95 & 64 & 50 & 77 & 77 & 55 & 91 & 75 \\
\hline Difference & 9 & 0 & 0 & 22 & 13 & 23 & 13 & 13 & 40 & 9 & 5 & 9 & 13 & 14 & 5 & 13 \\
\hline \hline
\end{tabular}

TABLE 4. Comparison of pretest and posttest scores, individual questions chosen correctly

\begin{tabular}{cccc}
\hline \hline Student & Pretest \% & Posttest \% & Difference \\
\hline S1 & 60 & 73 & +13 \\
\hline S2 & 60 & 80 & +20 \\
\hline S3 & 60 & 80 & +20 \\
\hline S5 & 53 & 73 & +20 \\
\hline S6 & 33 & 67 & +34 \\
\hline S7 & 66 & 53 & -13 \\
\hline S8 & 53 & 60 & +7 \\
\hline S9 & 47 & 53 & +6 \\
\hline S10 & 60 & 60 & +7 \\
\hline S11 & 53 & 60 & -14 \\
\hline S12 & 67 & 53 & -40 \\
\hline S13 & 53 & 53 & +54 \\
\hline S14 & 93 & 53 & 0 \\
\hline S15 & 33 & 87 & +40 \\
\hline S16 & 80 & 80 & +34 \\
\hline S17 & 40 & 80 & -13 \\
\hline S18 & 53 & 87 & +67 \\
\hline S19 & 80 & 73 & +27 \\
\hline S20 & 20 & 87 & -13 \\
\hline S21 & 60 & 87 & -13 \\
\hline S22 & 80 & 67 & +6 \\
\hline Overall & 73 & 60 & \\
\hline
\end{tabular}

\section{Analysis Table 3}

Overall results show a clear improvement of the issue among learners. Questions 4, 6 and 9 saw the greatest improvement. Questions 4 and 6 fulfilled the third objective of the study, while Q9 fulfilled the first and second objectives of the study. The highest increase belonged to Q9. Question 9 states: "I believe people are liars by nature." It is very encouraging to see how influential the instruction has been in helping students change their attitude towards their fellow human beings. This can have far-reaching consequences for educators. 


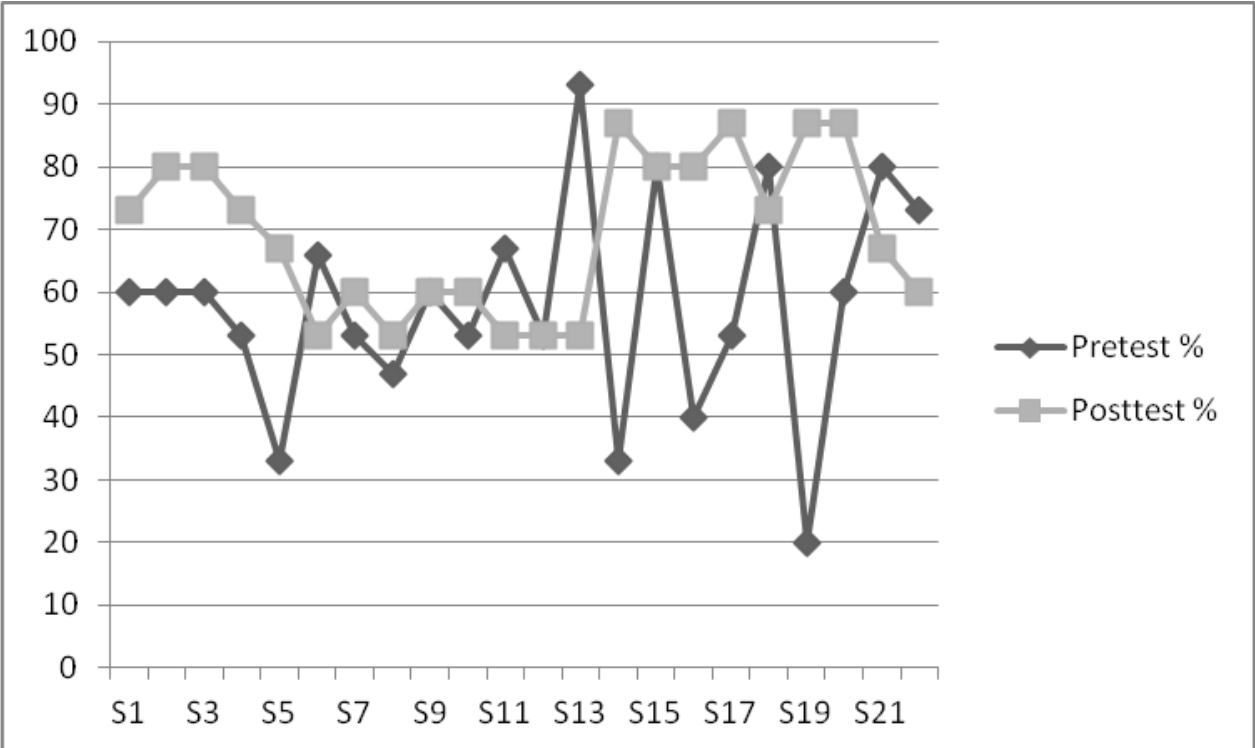

FIGURE 1. Comparison of pretest and posttest scores-individual questions chosen correctly

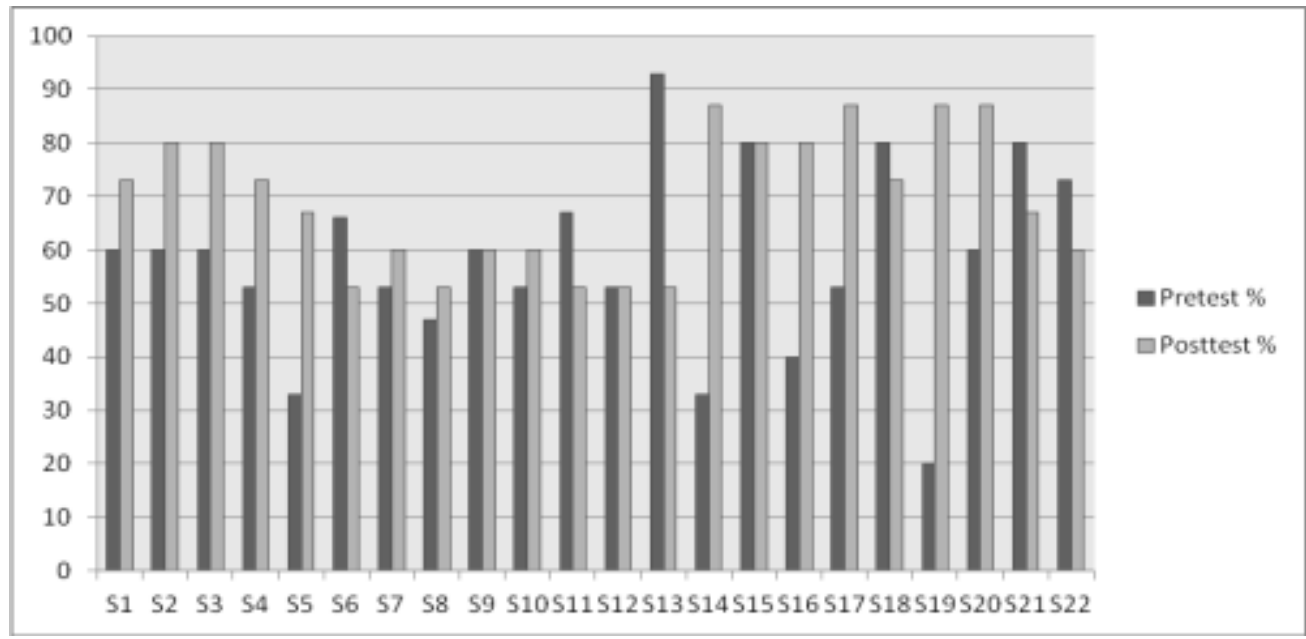

FIGURE 2. Comparisons of pretest and posttest scores-individual questions chosen correctly

\section{Analysis}

Overall results show a clear improvement of the issue among the learners. Students 19, 14, 5 and 17 saw the greatest improvement. Students 6, 11, 18, 21 and 22 showed regression; this was actually a kind of paradox! As a result, further research on this particular case became necessary. The author decided to interview students $6,11,18$ and 22 individually to find out the possible reasons for their regression. The interview revealed that students 6 and 22 made mistakes in their posttest because they just wanted to finish it, give it to the teacher and leave. Student 18 indicated that he was actually not feeling well, and he too wanted to finish it and depart. All three students offered to redo their posttest evaluation, something I did not agree to. Student 21 was adamant that he answered the posttest questions exactly the way he felt; as a result I did not feel it would be constructive to pursue the issue any further. I think the results are conclusive enough to tolerate this percentage of error. In 
future studies, when the number of learners increases, the error percentage could go even lower.

TABLE 5. Individual students' opinion on feedback on the questions

\begin{tabular}{|c|c|c|c|c|c|c|c|c|c|c|c|}
\hline $\begin{array}{l}\text { Items } \\
\text { Student }\end{array}$ & 1 & 2 & 3 & 4 & 5 & 6 & 7 & 8 & 9 & 10 & 11 \\
\hline S1 & $\mathrm{A}$ & $\mathrm{D}$ & A & D & $\mathrm{A}$ & $\mathrm{A}$ & D & $\mathrm{A}$ & D & $\mathrm{D}$ & A \\
\hline S2 & A & A & A & A & A & A & A & A & A & A & A \\
\hline S3 & $\mathrm{A}$ & $\mathrm{A}$ & $\mathrm{A}$ & SA & SA & A & A & A & A & $\mathrm{A}$ & A \\
\hline S4 & A & $\mathrm{A}$ & A & A & D & $\mathrm{D}$ & $\mathrm{A}$ & A & A & $\mathrm{A}$ & A \\
\hline S5 & SA & A & SA & SA & SA & SA & SA & SA & SA & SA & $\mathrm{SA}$ \\
\hline S6 & $\mathrm{A}$ & SA & A & A & SA & $\mathrm{A}$ & $\mathrm{A}$ & $\mathrm{A}$ & SA & $\mathrm{A}$ & SA \\
\hline S7 & SA & $\mathrm{A}$ & A & SA & SA & SA & $\mathrm{A}$ & A & SA & SA & SA \\
\hline S8 & $\mathrm{A}$ & SA & A & SA & $\mathrm{A}$ & SA & SA & SA & SA & SA & SA \\
\hline S9 & SA & SA & SA & SA & A & A & SA & SA & SA & SA & $\mathrm{SA}$ \\
\hline S10 & SA & SA & A & SA & SA & $\mathrm{D}$ & $\mathrm{A}$ & SA & SA & $\mathrm{A}$ & SA \\
\hline S11 & SA & $\mathrm{A}$ & SA & SA & A & $\mathrm{D}$ & $\mathrm{A}$ & D & A & $\mathrm{A}$ & D \\
\hline $\mathrm{S} 12$ & A & A & A & SA & SA & D & SA & SA & A & $\mathrm{D}$ & A \\
\hline $\mathrm{S} 13$ & $\mathrm{~A}$ & $\mathrm{~A}$ & SA & SA & $\mathrm{A}$ & $\mathrm{A}$ & $\mathrm{A}$ & $\mathrm{A}$ & A & SA & SA \\
\hline S14 & SA & SA & SA & SA & SA & A & SA & A & A & $\mathrm{A}$ & SA \\
\hline S15 & SA & $\mathrm{A}$ & SA & SA & SA & A & $\mathrm{A}$ & SA & A & SA & SA \\
\hline S16 & SA & $\mathrm{A}$ & SA & SA & SA & SA & SA & $\mathrm{A}$ & SA & SA & SA \\
\hline S17 & SA & $\mathrm{A}$ & $\mathrm{A}$ & SA & $\mathrm{A}$ & $\mathrm{A}$ & SA & SA & SA & SA & SA \\
\hline $\mathrm{S} 18$ & SA & A & SA & SA & SA & SA & SA & SA & SA & SA & $\mathrm{SA}$ \\
\hline S19 & $\mathrm{A}$ & $\mathrm{D}$ & A & A & A & A & A & A & A & A & A \\
\hline $\mathrm{S} 20$ & $\mathrm{~A}$ & $\mathrm{~A}$ & $\mathrm{~A}$ & SA & $\mathrm{A}$ & $\mathrm{D}$ & SA & $\mathrm{D}$ & SA & SA & A \\
\hline S21 & SA & SA & SA & SA & SA & $\mathrm{A}$ & $\mathrm{A}$ & SA & A & SA & SA \\
\hline $\mathrm{S} 22$ & A & $\mathrm{D}$ & A & A & A & SA & $\mathrm{A}$ & A & A & $\mathrm{A}$ & A \\
\hline
\end{tabular}

\section{Analysis}

The overall observation of the questionnaire is surprisingly clear. I mention surprisingly because I did not expect such a clear-cut positive response from the students, $46 \%$ of whom strongly agreed with the propositions. While $47 \%$ agreed, with only $7 \%$ disagreeing, no one strongly disagreed. I find these results very encouraging and I believe future studies conducted in a more thorough manner will show more reliable and influential results. I believe the questionnaire has been proven a very useful instrument in gauging the attitudes of students towards moral/ethical or spiritual education. It is noteworthy that although an overwhelming majority clearly indicated they learn morality from their families, a clear majority also indicated they would like to have more classes on moral education. This is very promising for researchers, as well as educators, who are concerned with the moral conditions of their subjects or students.

There are two more observations worthy of note; the first shows that students do not think that morality in society is very bad, and the second observation addresses the content of the lesson as not being easily understood. I think the 
feedback indicates that the lesson plan needs to be somewhat modified, perhaps including exercises to teach students to consider the future effects of both acceptable and unacceptable behavior on the individual, family and society.

\section{Lesson Plan}

The lesson plan gives a detail time allocation for the class. It basically covers pretest, teaching the quotation, teaching the story and the posttest. The topic of lesson is "Truthfulness," which was introduced as "the foundation of all human virtues." The teacher used an interactive-lecture format to teach a quotation which emphasized the importance of truthfulness. This was followed by a story emphasizing the application aspect of the principle of truthfulness being taught. Name of School: Pacific Junior High School Topic: The Use of Stories in Promoting Morality

Time: 40 minutes General Purpose:

To find out the effect of storytelling in the promotion of morality To bring the subject matter to the attention of students. To make students more conscious of the importance of the subject matter. To offer a means by which learners can implement the subject matter and bring about some changes in their daily lives.

TABLE 6. Activity framework

\begin{tabular}{|c|c|c|c|}
\hline Teaching Contents & Activity & Time & Medium \\
\hline Beginning & Teacher gives pretest. & 5 mins & Paper and Pencil \\
\hline $\begin{array}{l}\text { 1.0 Teaching truthfulness } \\
\text { and its importance. }\end{array}$ & Students read together. & 5 mins & Slide Projector \\
\hline 1.1 Explanation of the terms. & $\begin{array}{l}\text { Students are encouraged to ask } \\
\text { questions and clarify the terms }\end{array}$ & 5 mins & Slide projector \\
\hline 2.0 Telling the story. & used. & & \\
\hline 2.1 Explanation of the story & Teacher tells the story & 5 mins & Slide projector \\
\hline 2.2 Analysis of the story & Teacher explains the story. & 10 mins & Speech \\
\hline \multirow[t]{2}{*}{ 3.0 Posttest } & $\begin{array}{l}\text { Teacher asks students to share } \\
\text { what they have learned from } \\
\text { the story. }\end{array}$ & 5 mins & Speech \\
\hline & Teacher gives the posttest & $5 \mathrm{mins}$ & Paper and Pencil \\
\hline
\end{tabular}

\section{Instructional Contents}

The instructions for this one session class included two parts. The first part was the following quotation: "Truthfulness is the foundation of all human virtues. Without truthfulness progress and success... are impossible for any soul."

The second part was the following story by Aesop:

The Boy Who Cried Wolf

A shepherd-boy, who watched a flock of sheep near a village, brought out the villagers three or four times by crying out, "Wolf! Wolf!" and when his neighbors came to help him, laughed at them for their pains. 
The Wolf, however, did truly come at last. The Shepherd-boy, now really alarmed, shouted in an agony of terror: "Pray, do come and help me; the Wolf is killing the sheep"; but no one paid any heed to his cries, nor rendered any assistance. The Wolf, having no cause of fear, at his leisure lacerated or destroyed the whole flock.

There is no believing a liar, even when he speaks the truth.

The quotation was designed to emphasize the conceptual framework and the story was taught to provide the application component of the study.

\section{RESULTS}

The results of the pretest-posttest revealed the following: Out of fifteen questions, ten showed higher achievement, three had lower achievements and two stayed unchanged. Out of the fifteen questions, nine were on the application aspect and six were on the conceptual aspect of truthfulness. The majority of subjects clearly had consensus on the concepts. For example, most agreed that truthfulness is very important, and this understanding improved unanimously after the lesson was taught. However, the divergence occurred when it comes to actual application of the principle of truthfulness. Here are some statistical reports: of fifteen questions, $66 \%$ showed improvement, $20 \%$ showed decline and $14 \%$ stayed unchanged.

\section{CONCLUSION}

After looking at the pretest and posttest results, I can confidently conclude that a one hour session teaching morality did not produce any form of observable influence. A few words must be said with regards to "observable influence" in this context. In this particular study, two kinds of observable influences were considered. The first, obviously, should concern behavior, and this could not be measured, given constraints and limitations of the study. Behavioral observations require much greater scope, both in terms of time and number of research subjects. The second is awareness observation; that is, whether there was a greater awareness of the importance of morality among the research subjects after completion of one unit of instruction. The results showed a clear "yes" to this question.

\section{LIMITATIONS AND RECOMMEDNATIONS}

This study has its limitation to generalization, since it was performed using junior high school students and cannot be applied to the body of students at every level. The study is also limited, since it was conducted during one session lasting for forty minutes. Another limitation concerns the number of research subjects which was confined to about twenty students.

I would like to point out the amount of time dedicated to such an important topic was extremely limited. I believe further research is definitely needed to draw clear conclusions.

However, major modifications need to be made in the way such a study is conducted. Here are some considerations for future researchers on this topic:

- The aim of the study has to be clarified and its limitations need to be clearly understood.

- What are we measuring-an increase in awareness or improvement in behavior or both? 
- The greater the number of subjects, the more accurately an assessment can be made.

- The duration of study is a crucial one and it needs to be prolonged considerably.

- The frequency, as well as the number of instructional units, needs to be increased a great deal. I believe conducting sessions twice a week for a period of one school semester is a minimal requirement to reach meaningful conclusions.

- The nature of pretest and posttest questions can also be a contributing factor to a clearer reading of the results.

- An additional device can be introduced in the form of individual interviews with participants.

\section{REFERENCES}

Ayers, William.1992. In the country of the blind: Telling our stories. In Teacher lore: Learning from our own experience. New York, NY: Longman.

Bennett, William J. 1988. Moral literacy and the formation of character. NASSP Bulletin 72, no. 512: 29-3. Cambridge, UK: Cambridge University Press. DOI: 10.1177/019263658807251208

Cline, Erin M. 2007. Two senses of justice: Confucianism, rawls, and comparative political philosophy. Dao 6, 361-381. DOI: $10.1007 / \mathrm{s} 11712-007-9021-1$

Cline, Erin M. 2013. Confucius, rawls, and the sense of justice. New York, NY: Fordham University Press.

Cua, Antonio S. 1997. Moral vision and tradition: Essays in Chinese ethics. Washington, D.C., US: Catholic University of America Press.

Dick, Walter, and Lou Carey. 1985. The systematic design of instruction. 3 rd ed. New York, NY: Harper Collins.

Dworkin, Ronald. 1977. Taking rights seriously. Cambridge, MA: Harvard University Press.

Hare, Richard M. 1981. Moral thinking: Its levels, method and point. New York, NY: Oxford University Press. DOI: 10.1093/0198246609.001.0001

Hare, Richard M. 1982. Ethical theory and utilitarianism. In Utilitarianism and beyond, eds. Amartya Sen, and Bernard Williams. New York, NY: Cambridge University Press. 23-38. DOI: 10.1017/CB09780511611964.003

Hare, Richard M. 1989. Essays in ethical theory. New York, NY: Oxford University Press.

Judge, Devlin. 2015. Moral decline. URL: http://goo.gl/PqlyuH (accessed June 12, 2016).

Kohl, Herbert R. 1995. Should we burn Babar?: Essays on children's literature and the power of stories. New York, NY:

The New Press.

Kupperman, Joel. 1999. Learning from Asian philosophy. New York, NY: Oxford University Press.

Mager, Robert.1975. Preparing instrumental objective. 2nd ed. Belmont, CA: Fearon.

Naes, Arne, and Hanay, Alastair. 1972. Invitation to Chinese philosophy: Eight studies. Oslo, Norway: Universitetsforlaget. Nivison, David S. 1996. The ways of confucianism, ed. Bryan Van Nordan, La Salle, IL: Open Court.

Noddings, Nel. 1992. The challenge to care in schools: An alternative approach to education. New York, NY: Teachers College Press.

Power, F. Clark, Ann Higgins, and Lawrence Kohlberg. 1989. Lawrence Kohlberg's approach to moral education. New York, NY: Columbia University Press.

Stanford Encyclopedia of Philosophy. 2014. URL: http://goo.gl/dYH84f (accessed January 14, 2016).

Van Norden, Bryan. 2004. The virtue of righteousness in mencius," in Confucian ethics: A comparative study of self, autonomy, and community, eds. Kwong-Loi Shun, and David B. Wong. Cambridge, UK: Cambridge University Press.

Van Norden, Bryan. 2007. Virtue ethics and consequentialism in early Chinese philosophy. 
Williams, Bernard. 1981. Persons, character, and morality. In Moral luck, ed. James, Rachels. Cambridge, MA: Cambridge University Press. DOI: 10.1017/CB09781139165860

Yu, Jiyuan. 2007. The ethics of confucius and aristotle: Mirrors of virtue. New York, NY: Routledge. DOI: 10.1017/CB09780511497995

\section{APPENDIX}

\begin{tabular}{|c|c|c|c|c|c|}
\hline \multirow{2}{*}{\multicolumn{2}{|c|}{ Items }} & \multicolumn{4}{|c|}{ Number of Students } \\
\hline & & \multirow{2}{*}{$\begin{array}{r}\begin{array}{c}\text { Strongly } \\
\text { Agree (SA) }\end{array} \\
11\end{array}$} & \multirow{2}{*}{$\begin{array}{l}\begin{array}{l}\text { Agree } \\
\text { (A) } \\
11\end{array}\end{array}$} & \multirow{2}{*}{ 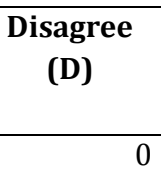 } & \multirow{2}{*}{$\begin{array}{c}\text { Strongly } \\
\text { Disagree } \\
\text { (SD) } \\
\end{array}$} \\
\hline 1. & Moral Education is important & & & & \\
\hline 2. & Morality is going down in the present society. & 7 & 13 & 3 & 0 \\
\hline 3. & Schools should teach morality. & 9 & 13 & 0 & 0 \\
\hline 4. & I learn morality from my family. & 16 & 5 & 1 & 0 \\
\hline 5. & I learn morality from my religion. & 11 & 10 & 1 & 0 \\
\hline 6. & The lesson was easy to understand. & 6 & 11 & 5 & 0 \\
\hline 7. & $\begin{array}{l}\text { The lesson was useful and practical for my } \\
\text { daily life. }\end{array}$ & 9 & 12 & 1 & 0 \\
\hline 8. & The way the lesson was taught was effective. & 9 & 11 & 2 & 0 \\
\hline 9. & $\begin{array}{l}\text { The lesson made me more aware of the } \\
\text { importance of moral education. }\end{array}$ & 10 & 11 & 1 & 0 \\
\hline 10. & $\begin{array}{l}\text { The contents were clear and easy to } \\
\text { understand. }\end{array}$ & 11 & 9 & 2 & 0 \\
\hline 11. & $\begin{array}{l}\text { I would like to have more classes on moral } \\
\text { education }\end{array}$ & 13 & 8 & 1 & 0 \\
\hline \multicolumn{2}{|c|}{ Overall } & 112 & 114 & 17 & 0 \\
\hline \multicolumn{2}{|c|}{ Overall in \% } & 46 & 47 & 7 & 0 \\
\hline
\end{tabular}

